\title{
Harmonic Analysis of 3-Phase Induction Motor at PT. Indocement Tunggal Prakarsa
}

\author{
Rahmat Adiprasetya Al Hasibi ${ }^{1}$, Slamet Suripto ${ }^{* 1}$, Rama Okta Wiyagi ${ }^{1}$, Candra Dwi Sukardi ${ }^{1}$, \\ Yessi Jusman ${ }^{1}$, Teguh Iman Prasetyo ${ }^{2}$ \\ ${ }^{1}$ Department of Electrical Engineering, Faculty of Engineering, Universitas Muhammadiyah Yogyakarta \\ Jl. Brawijaya, Tamantirto, Kasihan, Bantul, Yogyakarta, Indonesia \\ ${ }^{2}$ Production on the Job Trainer and Competence Assessor, Petroleum Development Oman \\ Muscat, Sultanate of Oman \\ *Corresponding author, e-mail: r.a.alhasibi@umy.ac.id
}

\begin{abstract}
In a developing country, the rate of electricity demand is increasing along with the increasing rate of population growth and the rate of economic development of the country. With the growing development of the use of electronic technology in power systems, more and more non-linear equipment is used in the industry. This non-linear equipment can affect power quality because this non-linear load is the primary source of harmonic interference. To minimize the impact of the harmonic generation that occurs on non-linear loads such as induction motors, harmonic filter equipment is needed. This study also compared the current and voltage THD levels based on the IEEE standard and performed calculations to design a single tuned passive filter. This calculation is done because of the emergence of harmonics on a 3-phase induction motor that has exceeded the standard limit, so it must reduce the harmonics. Moreover, disturbances that occur, such as torsion vibrations caused by the interaction of the fundamental harmonic magnetic field, causing higher noise. Furthermore, it leads to additional thermal stress on electric motors, which have an impact on reducing the life of motor insulation. Based on the comparison and analysis obtained that the measured current THD still exceeds the IEEE standard limits. Then the interference that arises in the 3-phase RAW MILL induction motor will have an adverse impact if not handled correctly and adequately.
\end{abstract}

Keywords: Harmonics, THD (Total Harmonic Distortion), Passive Single Tuned Filters

\section{Introduction}

Harmonics is a disturbance that occurs in an electric power distribution system due to the distortion of current and voltage waves [1]. Harmonics are symptoms of the formation of waves with different frequencies, which are multiplications of integers with their fundamental frequencies. This is called the harmonic frequency that arises in the original waveform, while the integer multiplier base frequency is called the harmonic sequence number. For example, the fundamental frequency of an electric power system is $50 \mathrm{~Hz}$, then the second harmonic is a wave with a frequency of $100 \mathrm{~Hz}$, the third harmonic is a wave with a frequency of 150
$\mathrm{Hz}$, and so on. These waves then ride on the original wave so that the deformed waves are formed, which is the amount of the momentary pure waves with the harmonic waves [2].

In electric power systems, there are two types of loads, namely linear loads and non-linear loads. The linear load is a load that provides a linear output waveform meaning that the current flowing is proportional to the impedance and voltage change. While the non-linear load is the output waveform is not proportional to the voltage in each half of the cycle so that the current waveform and the output voltage are not the same as the input wave (distorted) [3]. The non-linear load is generally an electronic device in which there are many semiconductor components, in the process of acting 
as a switch that works on each cycle of the voltage source. This work process will produce interference or distortion of current waves that are not sinusoidal. These waveforms are erratic and can change according to the settings of the semiconductor component parameters in electronic equipment. This waveform change is not related to the voltage source [4].

Some equipment that can cause harmonic effects to include computers, printers, fluorescent lamps that use electronic ballasts, motor speed control, induction motors, battery chargers, and electroplating processes. This equipment is designed to use electric current economically and efficiently because electric current can only pass through its semiconductor components during a predetermined regulatory period [5]. However, on the other hand, this will cause the wave to have a current and voltage wave disturbance, which will eventually return to other parts of the electric power system. This phenomenon will cause non-linear one phase load disturbance. Many of the above occur in distributions that supply office or commercial areas. Whereas in industrial areas, the disruption that occurs is non-linear three-phase load caused by electric motors, motor speed control, battery chargers, electroplating, and electric arc kitchens [6].

Each component of the distribution system can be affected by harmonics, even with different effects. However, these components will experience a decrease in performance and will even suffer damage. One common effect of harmonic interference is the overheating of neutral wire and transformers as a result of the emergence of the third harmonic generated by one-phase electrical equipment. Under normal circumstances, the load currents of each phase of a balanced linear load at the base frequency will reduce each other so that the neutral current becomes zero. On the other hand, a non-linear one-phase load will cause three-odd multiple harmonics called triple harmonics (3rd, 9th, 15th harmonic, and so on), which are often called harmonic zero sequences. This harmonic does not eliminate neutral currents but can produce neutral currents higher than phase currents [7].

In a developing country, the rate of electricity demand is increasing along with the increasing rate of population growth and the rate of economic development of the country. With this, it is necessary to increase the capacity of electricity generation. On the other hand, it is important to pay attention to the quality of the power from the existing electrical energy aside from the aspect of increasing capacity. In the electric power system it is known that a system will not be separated from the existence of both internal and external interference. The existence of these disturbances can trigger problems in the quality of a system's power. Electricity growth of a country is twice the economic growth. With economic growth, the people's purchasing power also increases. Increased purchasing power is characterized by the increasing number of non-linear electronic equipment owned by someone. On the other hand, with the growing development of the use of electronic technology in power systems, more and more non-linear equipment is used in industry. This non-linear equipment can affect power quality, because this non-linear load is the main source of harmonic interference. High levels of harmonics in electrical power systems are undesirable because they can cause harm [8].

Another important electrical problem observed is the harmonic phenomenon. To minimize the impact of harmonic generation on non-linear loads such as induction motors, harmonic filter equipment is needed. The existence of a harmonic phenomenon that occurs will cause a negative effect on electrical equipment, specifically the effects or impacts caused by harmonics on the electric power system that is the harmonic voltage can interfere with the control equipment used by electronic systems, cause errors in electrical measurement equipment, disrupt the tools safety in electric power systems such as relays and rotating machines such as generators and motors that can cause heat and vibration in these machine.

In the harmonics data found in PT. Indocement THDv harmonics in order 3.5 and 7 are obtained as follows: in order (3) $\mathrm{L}_{1}=0.25 \%, \mathrm{~L}_{2}=0.14 \%, \mathrm{~L}_{3}=$ $0.17 \%, \mathrm{~N}=91,65 \%$, at order $(5) \mathrm{L}_{1}=0.68 \%, \mathrm{~L}_{2}=$ $0.75 \%, \mathrm{~L}_{3}=0.72 \%, \mathrm{~N}=31.06 \%$ at order $(7) \mathrm{L}_{1}=$ $0.78 \%, \mathrm{~L}_{2}=0.74 \%, \mathrm{~L}_{3}=0.75 \% \mathrm{~N}=11.37 \%$ IEEE standard voltage harmonic on the bus $<69 \mathrm{kV}$ is $5 \%$. Then the measurement results THDi order (3) $\mathrm{L}_{1}=1.52 \%, \mathrm{~L}_{2}=2.6 \%, \mathrm{~L}_{3}=4.98 \%, \mathrm{~N}=35.59 \%$ in order (5) $\mathrm{L}_{1}=2.96 \%, \mathrm{~L}_{2}=2.92 \%, \mathrm{~L}_{3}=3.83 \%, \mathrm{~N}=$ $20.48 \%$ in the order $(7) \mathrm{L}_{1}=1.82 \%, \mathrm{~L}_{2}=2.92 \%, \mathrm{~L}_{3}$ $=3.83 \%, \mathrm{~N}=14.6 \%$ The IEEE standard current harmonics $<20 \mathrm{~A}$ in order $<11$ is $4 \%$ (data of August 2016).

Ribandono (2015) Conducted research at the Muhammadiyah University of Yogyakarta concerning Analysis of the Effects of Total Harmonic Distortion on the efficiency of Induction Motors. From this study it can be concluded that the THDi Large on a 3-phase induction motor using 
controls is greater than the THDi on a 3-phase induction motor without using controls with the results of the THDi data on a 3-phase induction motor using controls taken for example at a frequency of $90 \mathrm{~Hz}$ as much as $\mathrm{I}_{\mathrm{sa}}: 4.75 \%, \mathrm{I}_{\mathrm{sb}}$ : $6.95 \%$, and $\mathrm{I}_{\mathrm{sc}}: 7.71 \%$, while THDi on a 3 -phase induction motor without using control only amounted to $\mathrm{I}_{\mathrm{r}}: 1.04 \%$, Is: $1.31 \%$, and It: $586 \%$. This means that in a 3-phase induction motor using a control there is greater harmonics compared to a 3-phase induction motor without using control [9].

Muhammad Rusli (2009) Researched the Design of Single Turned Harmonic Filters as Current Harmonic Distortion Compensators (THDi) for Arc Furnaces customers in $20 \mathrm{kV}$ arc furnaces customers with an installed power of 3,115 kVA, supplied from 150/20 kV Sei Rotan substations. From this study it can be concluded that the individual current harmonic (IHDi) Arc Furnaces customers for orders 5, 11 and 23 exceed the IEEE 519-1992 standard. And the filter capacity needed to compensate for the 5th order harmonics on the power supply side (20 kV side) are: Capacitor 1,809 $\mathrm{kVar} / 30.15 \mathrm{~A}$, Inductor $150.14 \mathrm{Ohm}$ [10].

Zulkarnain (2009) researched the effect of harmonics on neutral currents, losses and decreases in capacity of the transformer at the Faculty of Engineering, University of Diponogoro. From this study it can be concluded that the loadings of transformers in transformers of chemical engineering, civil engineering, electrical engineering and mechanical engineering are very low where the loading is less than $25 \%$. The load from the distribution transformer is unbalanced and the THD current in the four transformers at certain times is in excess of the standard. As for THD, the voltage does not exceed the standard. The characteristics / composition of current harmonics in the four most dominant distribution transformers are the 3rd harmonics, the 5th harmonics and the 7th harmonics [11].

Likewise, factories in PT. Indocement due to the harmonic phenomenon are often ignored by some industries so that the impact can cause damage to electrical machines such as 3-phase induction motors that have to work continuously. So it is necessary to act to reduce harmonics by installing a harmonic filter on the factory electrical system that has not yet existed. The installation of filters is expected to minimize the impact that will occur.

\section{Methods}

1. Tools and Materials

The tools and materials used in this study consisted of Tools:
a. Acer Aspire one 722
b. 8 GB flash drive
c. 1 TB hard drive
d. Fluke series 435 Power Quality and Energy Analyzer.

Material:

a. Microsoft Office 2007.

b. Power Log Software as a measurement interface

\section{Research Time}

Research time for this final project is carried out starting from July 1, 2016, until March 10, 2017.

\section{Research Sites}

The location chosen as the basis for planning is carried out at PT. Indocement Tunggal Prakarsa Tbk which is located at Jalan Raya Palimanan km 20 Cirebon Palimanan, Cirebon, West Java province.

\section{Flowchart of Research}

Flowchart for the research is presented in Fig. 1.

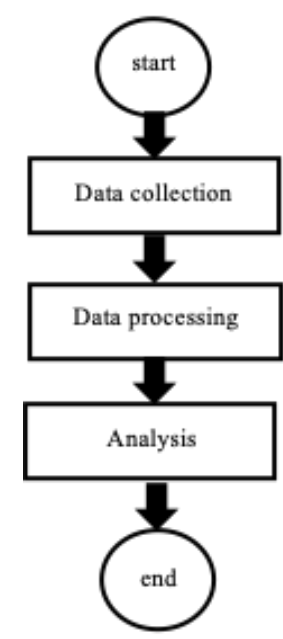

Fig. 1. Research flow chart

Based on the flow chart above, the research carried out includes the following steps:

1. Data collection

There are 2 (two) types of data in this study, namely primary data and secondary data.

a. Primary Data

The data collection was carried out by direct 
observation in the factory area of PT. Indocement Tunggal Prakarsa Tbk. And interviews with related technicians and conducted harmonics measurements on the RAW MILL SS E3 3-phase induction motor using a Power Quality and Energy Analyzer. The following primary data obtained from the results of harmonics measurements on 3-phase induction motors:

1. Fundamental Voltage and Current

2. Frequency

3. Voltage and Current

4. Voltage and Current Harmonics

5. THD (Total Harmonic Distortion) Voltage and Current

6. Cos Phi Voltage and Current

7. K-factor Current

b. Secondary Data

Data retrieval is done directly at PT. Indocement Tunggal Prakarsa Tbk. The purpose of this data retrieval is to obtain data relating to the final project research. The following data is obtained as documentation:

1. Specifications of 3-phase induction motor RAW MILL SS E3 PLANT 10

2. Single line diagram plant 10 PT. Indocement Tunggal Prakarsa Tbk.

\section{Data processing}

Based on the data that has been obtained then the results will be processed in the form of tables and graphs.

\section{Analysis}

Based on the data obtained in this study, an analysis will be performed to compare with the harmonics standard used in this thesis research. The harmonic standard used is IEEE std 519-1992. And calculate based on $\mathrm{L}$ and $\mathrm{C}$ on a passive filter (single tuned) to reduce the harmonic arising from a 3 -phase induction motor.

\section{Results and Discussion}

\section{III.1. Power Analyzer Measurement Scheme}

From Figure 2, it can be seen that there are two functions of the power analyzer which have three inputs for current and four inputs for voltage, where three inputs function to measure currents in phase $\mathrm{R}, \mathrm{S}, \mathrm{T}$ and four inputs to measure voltage in phase $\mathrm{R}, \mathrm{S}, \mathrm{T}, \mathrm{N}$. Equipment used to measure current using a current sensor or current clamp so that it is not necessary to open a circuit which uses the principle of magnetic induction. The principle of magnetic induction is the magnetic field strength due to the electric current flowing in the conductor. Meanwhile, to measure the voltage using a crocodile pinch or a clamp voltage clamped on the screw connected to the phase voltage $\mathrm{R}, \mathrm{S}, \mathrm{T}$, and Neutral.

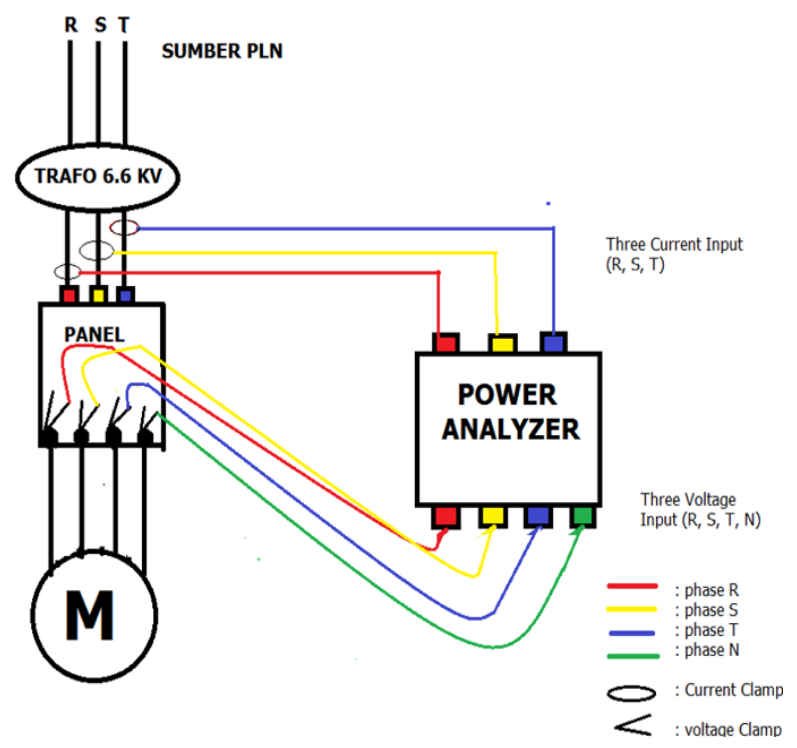

Fig. 2. Installation of power analyzer measuring instruments on the RAW MILL motor panel

The following data are obtained from the measurement of harmonics on a 3-phase induction motor:

1. Fundamental Voltage and Current

2. Active Power

3. Reactive Power

4. Pseudo power

5. Voltage and Current

6. THD (Total Harmonic Distortion) Voltage and Current

7. Cos Phi

\section{III.2. Description of Current THD Measurement}

From the measurement results in Figure 4, it can be seen that the maximum harmonic current THD value on line 1 is at 15:38:54 with a value of $4.68 \%$ almost close to the IEEE standard limit, while the minimum harmonic current THD value is at $15: 19: 24$ with a value of $3.45 \%$. On line 2 , the maximum current THD value is 15:38:04 with $7.07 \%$, this value has exceeded the IEEE standard. While the minimum current THD value is at 15:20:04 with a value of $3.38 \%$. Then in line 3 the 
maximum current THD value is at 15:40:14 with a value of $12.03 \%$, this value has exceeded the IEEE standard. While the minimum current THD is at $15: 22: 24$ with a value of $3.21 \%$. Then from the data in Figure 4, it can be seen that the maximum current THD value is at 15:36:54 with a value of $12.23 \%$ in line 3 and the minimum current THD is at 15:22:24 with a value of $3.21 \%$ in line 3 .

\section{III.3. Comparison of Harmonic Current THD with IEEE Harmonization Standards}

Comparison of Harmonic Current THD values with IEEE standards. The value of the short circuit current or Isc can be seen from the ETAP simulation results in the short circuit report table that is equal to Isc $=1624$ amperes and the maximum load current or IL is equal to $\mathrm{IL}=264.6$ amperes. Then the ratio value of Isc: $\mathrm{IL}=6: 1=6$ so that the value of the short circuit current (Isc) is 6 times greater than the load current (IL) so the value of Isc / IL <20. In Figure 4, the measurement results show that the maximum current THD in order 1 to 50 arising from induction motors that is equal to $12.03 \%$ in order $>35$. Thus THD has exceeded the allowable limit of the IEEE standard of 5\%. That the maximum harmonic current THD value on line 3 is at 15:36:54 with a value of $12.23 \%$, and the minimum current THD is at 15:22:24 with a value of $3.21 \%$ on line 3 .

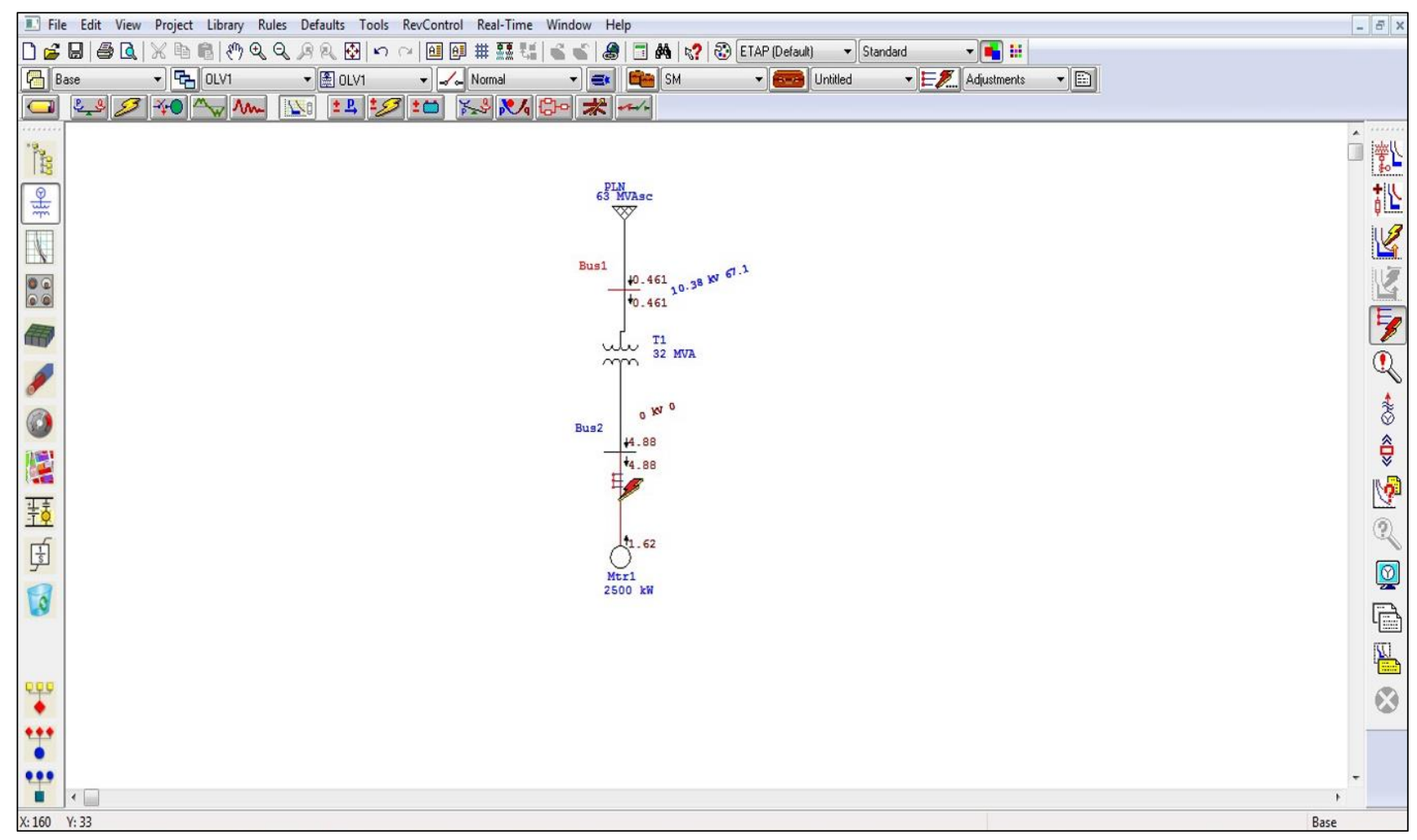

Fig. 3. ETAP simulation looking for short circuit current (Isc) on the motor

TABLE I

IEEE 519-1992 HARMONICS STANDARD FOR CURRENT

\begin{tabular}{ccccccc}
\hline \hline Value & \multicolumn{5}{c}{ IHD value for each order $(\%)$} & \multirow{2}{*}{ THDi $(\%)$} \\
\hline Isc/IL & $<11$ & $11 \leq \mathrm{h}<17$ & $17 \leq \mathrm{h}<23$ & $23 \leq \mathrm{h}<35$ & $35>\mathrm{h}$ & \\
\cline { 1 - 6 } 20 & 4.0 & 2.0 & 1.5 & 0.6 & 0.3 & 5.0 \\
$20-50$ & 7.0 & 3.5 & 2.5 & 1.0 & 0.5 & 8.0 \\
$50-100$ & 10.0 & 4.5 & 4.0 & 1.5 & 0.7 & 12.0 \\
$100-1000$ & 12.0 & 5.5 & 5.0 & 2.0 & 1.0 & 15.0 \\
$>10000$ & 15.0 & 7.0 & 6.0 & 2.5 & 1.4 & 20.0 \\
\hline \hline
\end{tabular}




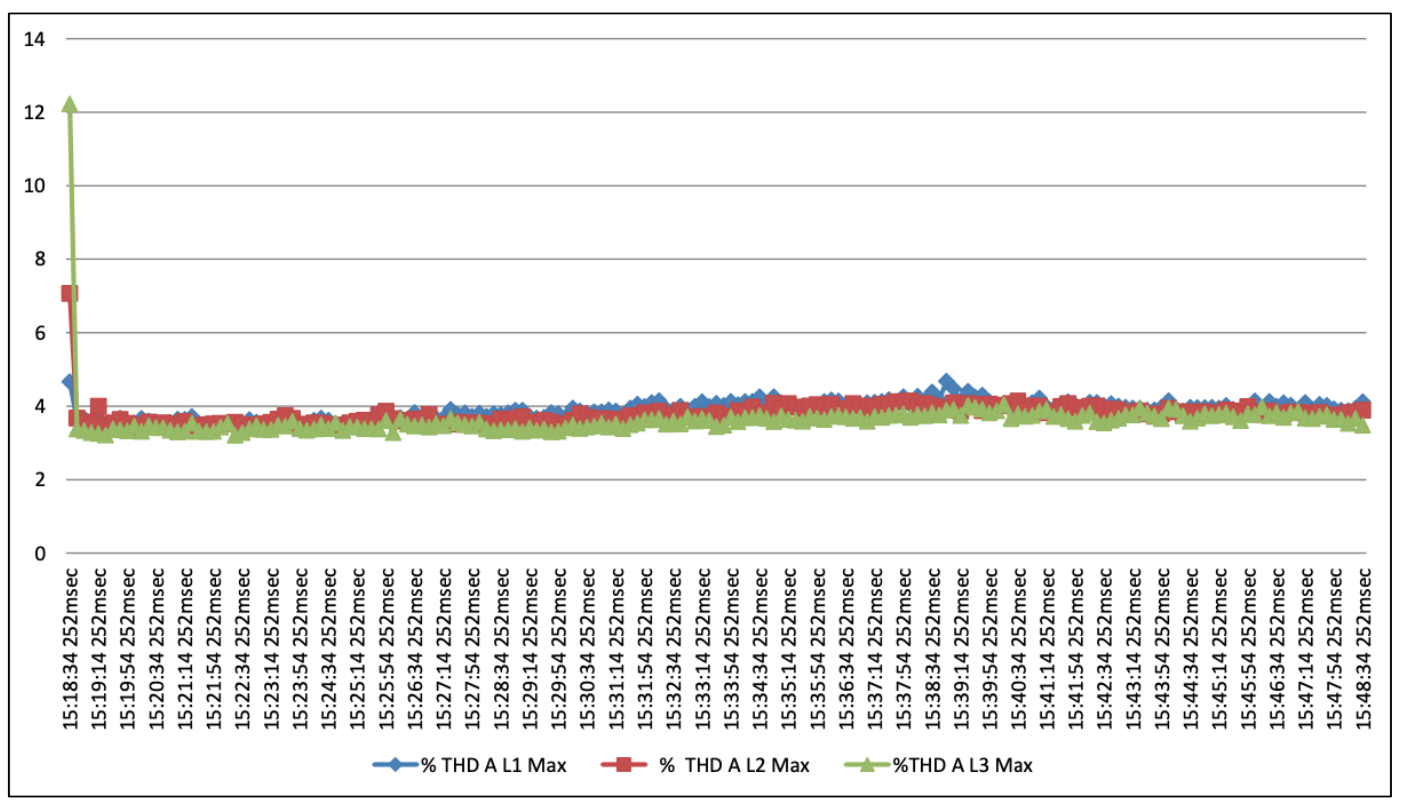

Fig. 4. THD graph of current with respect to time

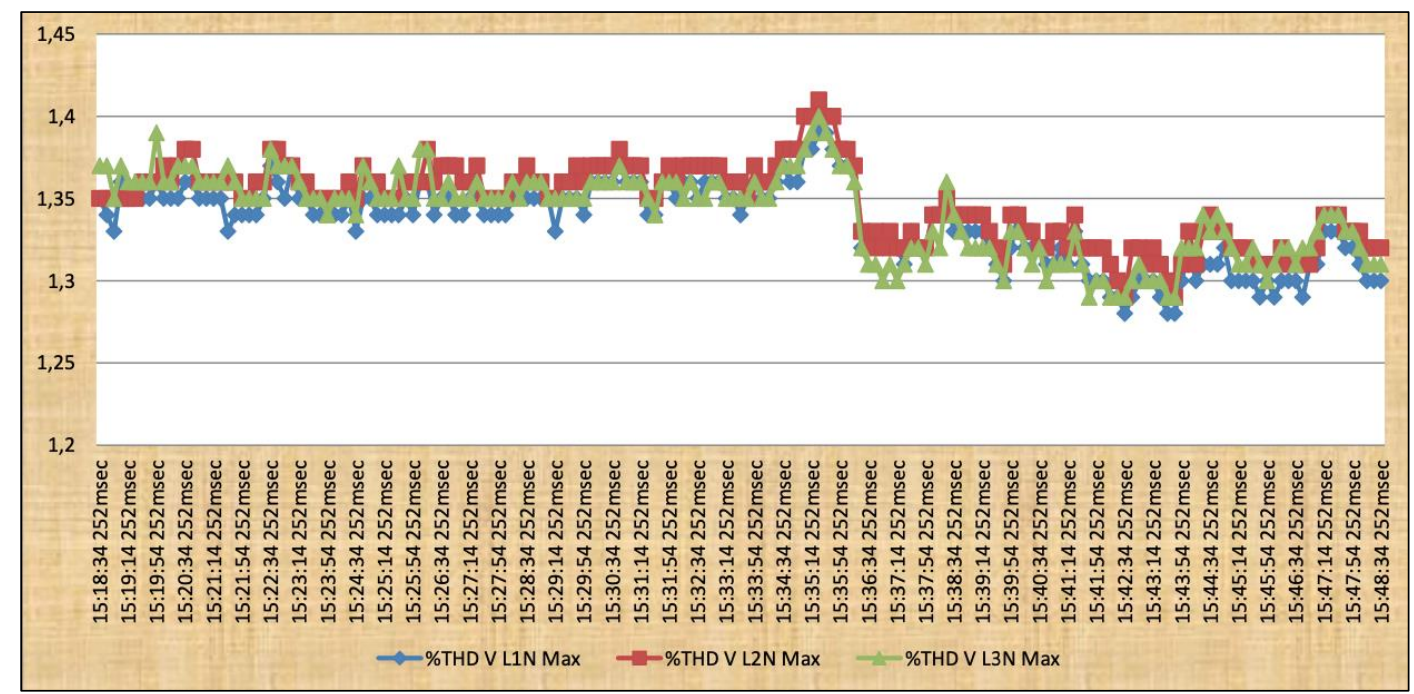

Fig. 5. THD graph of voltage with respect to time

\section{III.4. Voltage THD Measurement}

Measurements were taken on August 4, 2016 from 15:18:34 to 15:48:34. A Graph of data collection can be seen in Figure 5. From the results of measurements in Figure 5, it can be seen that the maximum harmonic voltage THD value on line 1 is at $15: 35: 24$ with a value of $1.39 \%$, while the minimum harmonic voltage THD value is at $15: 42: 34$ with a value of $1.28 \%$. On line 2 , the maximum voltage THD value is at 15:35:24 with a value of $1.41 \%$, while the minimum voltage THD value is at $15: 43: 44$ with a value of $1.29 \%$. Then on line 3 the maximum voltage THD value is at $15: 35: 24$ with a value of $1.4 \%$, while the minimum voltage THD is at 15:43:34 with a value of $1.29 \%$.
So from these data it can be seen that the maximum voltage THD value is at 15:35:24 with a value of $1.41 \%$ on line 2 and the minimum voltage THD is at $15: 42: 34$ with a value of $1.28 \%$ on line 1 .

\section{III.5. Comparison THD Voltage with IEEE Harmonization Standards}

In Figure 5, it can be seen that the maximum THD voltage arising on a 3 -phase induction motor is still within the allowable limit of the IEEE standard that is less than $5 \%$. And the data recorded on the THD voltage the maximum value on line 2 is at $15: 35: 24$ with a value of $1.41 \%$. And the minimum harmonic voltage THD value is at $15: 42: 34$ with a value of $1.28 \%$ on line 1 . 
TABLE II

IEEE 519-1992 HARMONICS STANDARD FOR VOLTAGE

\begin{tabular}{ccc}
\hline \hline Bus Voltage & IHDV $(\%)$ & THDV $(\%)$ \\
\hline$<69 \mathrm{kV}$ & 3.0 & 5.0 \\
$69-161 \mathrm{kV}$ & 1.5 & 2.5 \\
$\geq 161 \mathrm{kV}$ & 1.0 & 1.5 \\
\hline \hline
\end{tabular}

\section{III.6. Analysis of Harmonic Impacts Arising in 3- phase Induction Motors}

Because of the measurement results obtained there are harmonics that exceed the IEEE standard limits, the impacts arising from 3-phase induction motor harmonics such as:

1. Copper and iron losses increase resulting in heating.

2. Torque vibrations are caused by interactions of the basic harmonic magnetic field. This makes higher noise.

3. Causing additional thermal stress on electric motors which has an impact on reducing the insulation life of the motor.

\section{III.7. Passive filters single tuned}

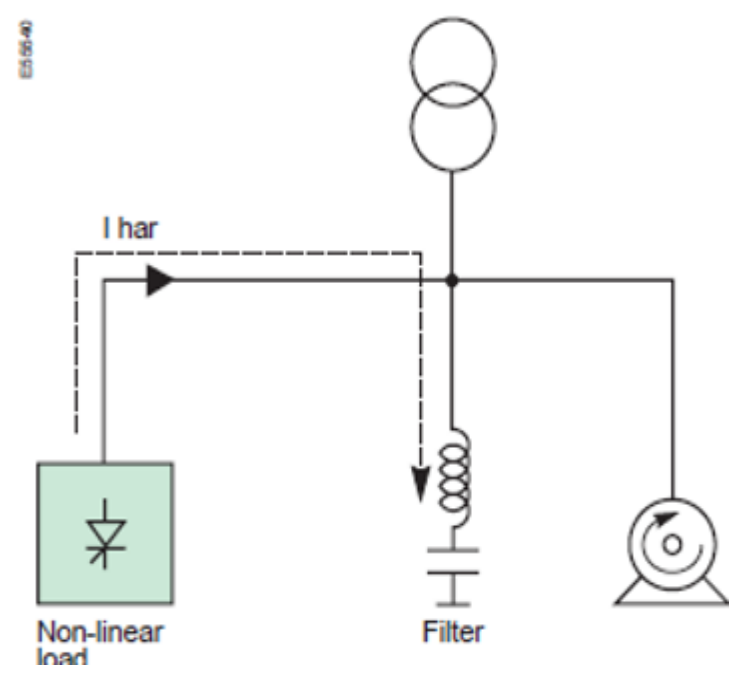

Fig. 6. Scheme of installing a single tuned passive filter

Passive filters are mostly designed to provide special parts to divert unwanted harmonic currents in the electric power system. Passive filters function to reduce certain frequencies of a voltage or current. By providing a low path for its impedance at harmonic frequencies. The main components contained in the passive filter are capacitors (C) and inductors (L), as can be seen in Figure 6. Capacitors are connected in series or parallel to obtain a desired total voltage and reactive power (KVAR) rating, while the inductor used in the filter circuit is designed to be able to withstand high frequency sheaths which are skin effects. Passive filter installation is usually placed near electric power, this is intended to prevent harmonic to the source. To design this filter we need the highest harmonic voltage $\left(\mathrm{THD}_{\mathrm{V}}\right)$ and current $\left(\mathrm{THD}_{\mathrm{I}}\right)$ distortion data in the system. The biggest voltage harmonic data is used to determine the harmonic current of what order will be filtered from the system. Criteria based on harmonic voltage are more appropriate for filter design. This is because it is easier to guarantee to be within a reasonable voltage limit than to limit the current level due to the AC network impedance.

\section{III.8. Design of Passive Singel Tuned Filters}

To design a filter, it is necessary to first identify the process of harmonic order that is to be suppressed. Because a single tuned passive filter can only absorb one order, the greatest voltage harmonic will be used to design a single tuned passive filter.

TABLE III

THD ORDER 3

\begin{tabular}{|c|c|}
\hline \multicolumn{2}{|c|}{ Order 3 Max } \\
\hline Voltage (V) & THD \% \\
\hline Line 1 & 0.25 \\
\hline Line 2 & 0.14 \\
\hline Line 3 & 0.17 \\
\hline Current (A) & THD \% \\
\hline Line 1 & 1.52 \\
\hline Line 2 & 2.6 \\
\hline Line 3 & 4.98 \\
\hline \multicolumn{2}{|c|}{$\begin{array}{c}\text { TABLE IV } \\
\text { THD ORDER } 5 \\
\end{array}$} \\
\hline \multicolumn{2}{|c|}{ Order 5 Max } \\
\hline Voltage (V) & THD \% \\
\hline Line 1 & 0.68 \\
\hline Line 2 & 0.75 \\
\hline Line 3 & 0.72 \\
\hline Current (A) & THD \% \\
\hline Line 1 & 2.96 \\
\hline Line 2 & 2.92 \\
\hline Line 3 & 3.83 \\
\hline
\end{tabular}

TABLE V

THD ORDER 7

\begin{tabular}{cc}
\hline & Order 7 Max \\
\hline Voltage (V) & THD \% \\
Line 1 & 0.78 \\
Line 2 & 0.74 \\
Line 3 & 0.75 \\
\hline Current (A) & THD \% \\
Line 1 & 1.82 \\
Line 2 & 1.93 \\
Line 3 & 2.81 \\
\hline \hline
\end{tabular}




\section{III.9. Singel Tuned Passive Filter}

Calculation Based on measurement data from Table III, Table IV, and Table V, it can be seen that the greatest voltage harmonic is in order 7 , so the passive filter to be designed will dampen harmonic order 7.

Note:
a. Motor voltage $=6.6 \mathrm{kV}$
b. Reactive power on capacitor $\left(\mathrm{Q}_{\mathrm{c}}\right)=0.4 \mathrm{MVAr}$
c. Harmonic order (n) $=7$

1. To calculate the capacitive reactance, the $\mathrm{Q}_{\mathrm{c}}$ value is derived from the value of the reactive power capacity of the capacitor bank used.

$$
\begin{aligned}
& \mathrm{Xc}=\frac{\mathrm{kV^{2 }}}{\mathrm{Qc}} \\
& =\frac{6.6^{2} \mathrm{kV}}{400 \mathrm{kV} \mathrm{Ar}} \\
& =0.1089 \mathrm{k} \Omega
\end{aligned}
$$

2.

$$
\begin{gathered}
\mathrm{X}_{\mathrm{L}}=\frac{\mathrm{Xc}}{\mathrm{n}^{2}} \\
=\frac{108.9 \Omega}{7^{2}} \\
=2.22 \mathrm{k} \Omega \\
\mathrm{Xn}=\sqrt{\mathrm{Xl} . \mathrm{Xc}} \\
\mathrm{Xn}=\sqrt{2.22 \times 108.9} \\
=15.5 \Omega
\end{gathered}
$$

3. To calculate the reactor resistance filter quality factor value $\mathrm{Q}=100$

$$
\begin{aligned}
R & =\frac{X n}{Q} \\
R & =\frac{15.5}{100}
\end{aligned}
$$

4.

$$
\begin{gathered}
\mathrm{L}=\frac{\mathrm{Xt}}{2 . \pi . \mathrm{f}} \\
\mathrm{L}=\frac{2.22}{2 \times 3.14 \times 50} \\
\mathrm{~L}=7.07 \times 10^{-3} \mathrm{H}
\end{gathered}
$$

5.

$$
\begin{gathered}
\mathrm{C}=\frac{1}{2 . \pi \cdot \mathrm{f} . \mathrm{Xc}} \\
=\frac{1}{2 \times 3.14 \times 50 \times 108.9}
\end{gathered}
$$

$$
=2.92 \times 10^{-5} \mathrm{~F}
$$

6.

$$
\begin{gathered}
\mathrm{Q}_{\text {filter }}=\frac{\mathrm{kV}^{2}}{X c-X l} \\
\mathrm{Q}_{\text {filter }}=\frac{6.6^{2}}{108.9-2.22} \\
\mathrm{Q}_{\text {filter }}=0.408 \mathrm{MVAr}
\end{gathered}
$$

TABLE VI

Single Tuned Passive Filter Specifications

\begin{tabular}{cc} 
SinGLe Tuned PASSIVE FILTER SPECIFICATIONS \\
\hline \hline \multicolumn{2}{c}{ Single Tuned Passive Filter Specifications } \\
\hline Specifications & Value \\
Xc & $108.9 \Omega$ \\
XL & $2.22 \Omega$ \\
Xn & $15.5 \Omega$ \\
R & $0.155 \Omega$ \\
L & $7.07 \times 10^{-3} \mathrm{H}$ \\
C & $2.92 \times 10^{-5} \mathrm{~F}$ \\
Qfilter & $0.408 \mathrm{MVAr}$ \\
\hline Specifications & Value \\
Xc & $108.9 \Omega$ \\
XL & $2.22 \Omega$ \\
\hline \hline
\end{tabular}

From the calculation results obtained specifications for a single tuned filter are the capacitor reactance value $\mathrm{X}_{\mathrm{C}}=108.9 \Omega$, the inductor reactance value $\mathrm{X}_{\mathrm{L}}=2.22 \Omega$, the reactance value of the muted order characteristic $X_{n}=15.5 \Omega$, the reactor reactance $\mathrm{R}=0.155 \Omega$, the inductor $\mathrm{L}$ value $=7.07 \times 10^{-3} \mathrm{H}$, capacitor value $\mathrm{C}=2.92 \times 10^{5}$ $\mathrm{F}$ then the passive filter capacity $\mathrm{Q}_{\text {filter }}=0.408$ MVAr. The specifications of the single tuned filter were shown in Table 6 .

\section{Conclusion}

Based on the results obtained from calculations and analysis, the following conclusions can be drawn:

1. Comparison of the THD value of the harmonics current with the IEEE standard. The value of the short circuit current or Isc can be seen from the simulation results in the short circuit report table, namely $\mathrm{I}_{\mathrm{sc}}=1624$ amperes. And the maximum load current or $\mathrm{I}_{\mathrm{L}}$ can be seen from table 4.2 i.e. $\mathrm{I}_{\mathrm{L}}=264.6$ amperes. Then the comparison value $I_{s c}: I_{L}=6: 1=6$ so that the value of $6 I_{s c}$ times $I_{L}$ becomes the value of Isc $/ I_{L}<20$. In figure 4 , the measurement results show that the maximum current THD in order 1 to 50 arising on the induction motor is $12.03 \%$ in order $>35$. Thus THD has exceeded the allowable limit of the IEEE standard of $5 \%$. That the maximum harmonic current THD value on line 3 is at 
15:36:54 with a value of $12.23 \%$, and the minimum current THD is at 15:22:24 with a value of $3.21 \%$ on line 3 .

2. Comparison of the voltage THD value harmonics with IEEE standards. In the measurement table 4.5 above it can be seen that the maximum THD voltage arising on a 3-phase induction motor is still within the allowable limit of the IEEE standard of less than 5\%. And the data recorded on the THD voltage the maximum value on line 2 is at 15:35:24 with a value of $1.41 \%$. And the minimum harmonic voltage THD value is at $15: 42: 34$ with a value of $1.28 \%$ in line 1.

3. From the calculation results, the specifications for a single tuned filter are the capacitor reactance value $X_{c}=108.9 \Omega$, the reactor value of $\mathrm{X}_{\mathrm{L}}$ inductor $=2.22 \Omega$, the characteristic reactance value of the muted order $X_{n}=15.5 \Omega$, the reactor reactance $\mathrm{R}=0.155 \Omega$, the value of the inductor $\mathrm{L}=7.07 \times 10^{-3} \mathrm{H}$, the capacitor value $\mathrm{C}=2.92 \times 10^{-5} \mathrm{~F}$ then the passive filter capacity $\mathrm{Q}_{\text {filter }}=0.408 \mathrm{MVAr}$.

\section{Acknowledgements}

This work was supported by Universitas Muhammadiyah Yogyakarta.

\section{References}

[1] T. Gönen, Electric Power Distribution System Engineering, Florida: CRC Press, 2008.

[2] Malik Sameeullah, Jitendra Kumar, Kanhaiya Lal, Jagdish Chander, "Energy Audit: A Case Study of Hostel Building", International Journal of Research in Management Science \& Technology, vol. 2, no. 2, August 2014.

[3] T. Woolley, S. Kimmins, P. Harrison and R. Harrison, Green Building Handbook, New York: E \& FN Spon, 1997.

[4] E. C. Quispe, I. D. Lopez, "Effects of unbalanced voltages on the energy performance of three phase induction motors", IEEE conf. on Power Electronics and Power Quality Applications, pp. 1-6, July 2015.

[5] A. B. Neves, M. V. B. Mendonça, A. L. F. Filho, G. Z. Rosa, "Effects of voltage unbalance and harmonic distortion on the torque and efficiency of a three phase induction motor", 17th International Conference on Harmonics and Quality of Power (ICHQP), 2016.

[6] J. Huang, Z. Jiang, "Power quality assessment of different load categories", 4th International Conference on Power and Energy Systems
Engineering CPESE 2017, 25-29 September 2017.

[7] W.A Elhaija, A. Muetze, "A voltage unbalance factor coding technique for three phase induction motors", Int Trans Electr Energ Syst., 2018.

[8] K. Arung, "Analisa Daya dan Filter Harmonik Orde 5 di Pabrik Wire ROD MILL PT.Krakatau Steel (Persero) TBK. UGM," Yogyakarta, 2014.

[9] B. Ribandono, "Analisa Pengaruh Distorsi Harmonik Total terhadap efisiensi Motor Induksi,” Universitas Muhammadiyah Yogyakarta, 2015.

[10]M. Rusli, "Desain Filter Harmonisa Single Turned Sebagai Kompensator Distorsi Harmonisa Arus (THDi) Pelanggan Arc Furnaces," 2009.

[11]I. Zulkarnain, "Analisis Pengaruh harmonisa Terhadap Arus Netral, Rugi-rugi dan Penurunan Kapasitas pada Transformator Distribusi," Universitas Diponogoro Semarang, 2009.

\section{Authors' information}

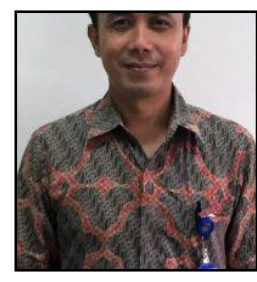

Rahmat Adiprasetya Al Hasibi obtained his B.Eng. in Electrical Engineering from Universitas Gadjah Mada, Indonesia in 2001. His Master study was done at the Electrical Engineering, Universitas Gadjah Mada, Indonesia. He currently is a lecture in department of electrical engineering, Universitas Muhammadiyah Yogyakarta. His research interests are in power system analysis, renewable energy, distributed generation system, power system protection, and optimization.

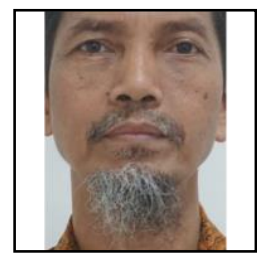

Slamet Suripto obtained his B.Eng. in Electrical Engineering from Universitas Gadjah Mada, Indonesia in 1987. His Master study was done at the Electrical Engineering, Universitas Gadjah Mada, Indonesia. He currently is a lecture in department of electrical engineering, Universitas Muhammadiyah Yogyakarta.

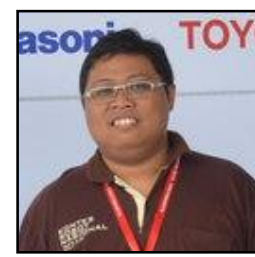

Rama Okta Wiyagi obtained his B.Eng. in Electrical Engineering from Universitas Muhammadiyah Yogyakarta, Indonesia in 2009. His Master study was done at 2015 at the Electrical Engineering, Universitas Gadjah Mada, Indonesia. He currently is a lecture in department of electrical engineering, Universitas Muhammadiyah Yogyakarta.

Candra Dwi Sukardi obtained his B.Eng. in Electrical Engineering from Universitas Muhammadiyah Yogyakarta, Indonesia in 2017.

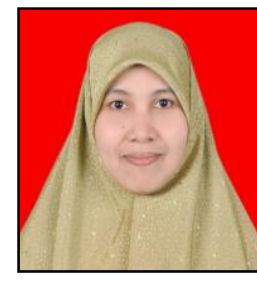

Yessi Jusman obtained her B.Eng. in Electrical and Electronic Engineering from Andalas University, Indonesia in 2007. She worked as a Research Assistant started in July 2008 until November 2009 in Universiti Sains Malaysia. Her Master study was done at 2012 at the School of Electrical and Electronic Engineering, 
USM Engineering Campus in Nibong Tebal, Penang, Malaysia. She was finished her PhD degree at 2016 in University of Malaya with specializes in Image, Signal Processing, and algorithms. She currently is a lecture in department of electrical engineering, Universitas Muhammadiyah Yogyakarta.

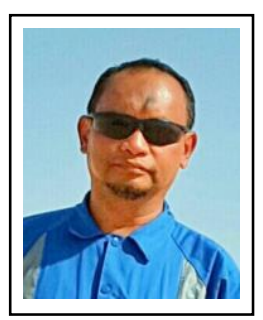

Teguh Iman Prasetyo hold a bachelor degree in 2000 from Electrical Engineering Department, Universitas Muhammadiyah Yogyakarta, Indonesia. Mr. Teguh Iman Prasetyo is currently a professional in Production on the Job Trainer and Competence Assessor, Petroleum Development Oman, Muscat, Sultanate of Oman. His main research interest is in control system and distributed control system. 